\title{
Constraints being Faced by the Farmers in the Production of Major Field Crops in the State of Rajasthan, India
}

\author{
B. L. Verma* and R. C. Kumawat \\ Department of Agricultural Economics, SKN College of Agriculture, \\ Jobner (SKNAU,Jobner) : 303329, India \\ *Corresponding author
}

\begin{abstract}
A B S T R A C T
This study was conducted in the state of Rajasthan. Four major crop groups viz; cereals (pearlmillet, maize and wheat), pulses (moong bean, moth bean, kharif pulses and gram), oilseeds (soyabean and rapeseed and mustard) and others (cotton and clusterbean ) were selected for analysis. All the crops in the above groups having five per cent or more area under cultivation in a district were selected. The districts were selected on the basis of last five years average (2005-06 to 2009-10). The main krishi upaj mandi from each district generally located at its headquarters was selected purposively. From each mandi one commission agent was selected at random basis and 10 of the farmers who were available on the day of interview at the mandi were randomly interrogated. Thus a total number of $10 \times 29=290$ farmers were selected for studying the constraints faced by the farmers. Primary data were collected for the agricultural year 2014-15. The timely non-availability of inputs like HYV seeds, chemical fertilizers, plant protection chemicals etc at village level was one of the major production constraints faced by the cultivators of major field crops. High cost of improved variety seeds was the major economic problem. The lack of irrigation facilities was one of the major technical problems followed by no protection of crops from adverse weather conditions. Nonavailability of the inputs on time in the market for production of crops was one of the major infrastructural problems. The lack of cash for down payment was one of the major financial problems and low and imbalanced rate of fertilizer consumption was one of the major other constraints in the study area.
\end{abstract}

\section{Introduction}

Agricultural development of India has been agitating the minds of Indian politicians, the policy makers, the planners, the agricultural scientists and farmers since independence. A number of agricultural development plans gave rise to institutional and technological changes in the food grains production in the country. There are many empirical studies witnessing that the area under some crops increased over time while under some others it either decreased and /or remained stagnant. Despite a technological breakthrough in agriculture, the Indian agriculture is still a gamble of monsoon.

This leads to high degree of risks and uncertainty in production, prices and farm incomes because the farmers are often not sure about the outcomes from agriculture due to weather and market induced risks. 
In spite of the impressive achievements, the Indian agricultural sector continues to face poor infrastructure conditions. As a result, the productivity levels of many major crops in India are not comparable with the yields obtained in agriculturally advanced countries. The country's agriculture has gained in strength and resilience since independence, although growth in agriculture is highly skewed over regions and crops.

Agriculture has also been an important sector in the state of Rajasthan due to large dependencies of the population. It contributes 24.76 per cent (2017-18) in State GSDP at constant prices 2011-12 (Economic Review 2017-18 published in february-2018). Though the share of agriculture sector has been declining or stagnant over time, it still remains a predominant sector in respect of labour absorption. The sector, therefore, deserved to be assigned due importance for its sustainable and balanced development at the state level too. Therefore, different development programmes were initiated in every Five Year Plan covering different aspects of agricultural development. Land is one of important factor of production and is fixed. The districts/ state level study will be useful to formulate micro-level agricultural policies.

\section{Materials and Methods}

Constraints being faced by the farmers in the production of major field crops were individually interviewing the respondents with the help of schedules specially designed for this purpose. Garrett's ranking technique was used to arrive at some conclusion.

\section{Garrett's ranking technique}

Garrett's ranking technique was used to analyze the problems faced by farmers growing major field crops. The farmers were asked to rank the factors that they were facing. The rankings of the factors assigned by the farmers were converted into per cent terms by using the following formula:

Per cent position $=\frac{100\left(\mathrm{R}_{\mathrm{ij}}-0.50\right)}{\mathrm{N}_{\mathrm{j}}}$

Where

$\mathrm{R}_{\mathrm{ij}}=$ Rank given for $\mathrm{i}^{\text {th }}$ item by $\mathrm{j}^{\text {th }}$ individual farmer

$\mathrm{N}_{\mathrm{j}}=$ Number of items ranked by $\mathrm{j}^{\text {th }}$ individual farmer

The per cent position of each rank thus obtained was converted into scores by referring to the tables given by Garrett and Woodworth (1969).

\section{Results and Discussion}

Information regarding the problems faced by the cultivators was obtained in consultation with the cultivation of major field crops. Garrett's ranking technique was used to rank the orders of problems. The prime advantage of this technique over simple frequency distribution was that the problems were arranged based on their severity from the point of view of respondents (Table-1).

The per cent position of each rank was calculated with the help of following formula:

$100(\mathrm{Rij}-0.50)$
$\mathrm{Nj}$

Where,

Rij $=$ Ranking given for $i^{\text {th }}$ item by $j^{\text {th }}$ individual farmer

$\mathrm{Nj}=$ Number of items ranked by $\mathrm{j}^{\text {th }}$ individual farmer

The per cent position of each rank thus obtained was converted into scores by 
referring to the tables given by Garrett's and Woodworth (1969). Then for each problem, the scores of individual farmer were added together and divided by the total number of farmers for whom scores were added. The prime advantage of this technique over simple frequency distributions is that the problems were arranged based on their severity from the point of view of respondents. Hence, the same number of respondents on two or more problems may have been given different ranks. The mean scores for all the problems were ranked by arranging then in order.

\section{Production constraints pertaining to the major field crops production}

Garrett ranking technique was used to analyse the production constraints faced by the respondent farmers in the production of major field crops. The overall scenario of production constraints faced by the cultivators revealed that non-availability of inputs like HYV seeds, chemical fertilizers, plant protection chemicals, etc., at village level was one of the major problems faced by the cultivators (Table-2). Farmers complained of shortage of HYV seeds, chemical fertilizers and plant protection chemicals during the sensitive cropping period of major field crops. So this led to low production. Poor marketing facility for the produce was the second major problem faced by the cultivators. As the farmers could not afford to sell their produce in the market so they had to sell the produce in local mandies at whatever price existing at that time. Lack of technical guidance in time was ranked as third. Lack of technical guidance during sensitive cropping periods for farmers was the important reason of low production. Most of the farmers complained of lack of prompt services. It was ranked as fourth in the study period. It was also reported by the farmers that credit facilities were not timely available to them for buying production inputs like HYV seed, chemical fertilizers, plant protection chemicals etc. So the crop production happened to be low. Insufficient fund to buy improved production inputs was ranked as fifth. High cost of improved production inputs required more credit facilities. This problem was ranked as sixth in study area. Poor quality of seed and plant protection chemicals ranked seventh.

Poor quality of land was ranked at eighth position. This was due to the inadequate fertilization and adoption of in appropriate crop rotation. So it is recommended to apply good quantity of fertilizer and adoption of appropriate crop rotation with organic manures to maintain the quality of land for long time. These results were in conformation with that reported by Shrey et al., (2015).

\section{Economic constrains}

Table- 4 depicts the overall scenario of economic constraints faced by the farmers growing major field crops. It is obvious from the table that high cost of improved variety seeds was one of the major problems faced by the farmers in growing major field cops. The farmers could not afford the improved variety seeds without economic support leading to low productivity. Problems regarding high cost of fencing of boundary wall ranked second and non-availability of loans from banks and government agencies to the farmers was ranked third. Because the farmers could not afford timely and required amount of loans as a result of investment by farmers in crop production activities was low. The table indicates that low and fluctuating price was fourth major economic problem in the study area. This might be attributed to seasonal nature of production of major field crops.

Problem of high cost of fertilizer faced by the farmers was ranked fifth. This was because of seasonal nature and uneven distribution of fertilizer. The sixth major problem reported 
by the farmers was high cost of irrigation water. It may be attributed to fast depleting water level coupled with irregular and interrupted electricity supply in that area. Shortage of human labour was the next major problem faced by the farmers growing major field crops. This was because of heavy demand of labour by the farmers cultivating different crops in the study area. So demand for labour was high and availability was less. Similar results were reported by Thanh and Singh (2006).

\section{Technical constraints}

It is evident from table- 6 that the lack of irrigation facilities was one of the major problems being faced by the farmers. It may be attributable to fast depleting ground water level in the study area. In order to improve irrigation efficiency, there is a need to develop water harvesting system to recharge water level. Problem regarding protection of crops from adverse weather conditions was ranked second. Protection from natural calamities is not easy but farmers should adopt protection measures against adverse weather conditions i.e. rainwater harvesting, mulching, mixed or intercropping, ridges and furrows, deep drainage, crop insurance etc.

Lack of technical knowledge about crop cultivation was ranked as third. The fourth major problem reported by the farmers was that they were not aware of name and doses of manures, fertilizers and chemicals. Limited use of short duration HYV seeds was fifth major problem faced by the major field crops cultivators. The table indicates that the incidence of diseases was sixth major technical problem in the study area. It was reported by the farmers that the seriousness of diseases could not be recognized in initial stage. Poor crop germination was ranked as seventh. The eight major problem reported by the farmers was the lack of soil testing facilities in study area. The ninth and last major problem reported by the farmers was that there were no direction and encouragement from administration for crop cultivation. These results were in conformation with that reported by Dhaka and Dhaka (2016) and Shashikant et al., (2013).

\section{Infrastructural constraints}

Table- 8 depicts the overall scenario of infrastructural constraints faced by the farmers growing major field crops. It is obvious from the table that non-availability of the inputs on time in the market for production of crops was one of the major problem. This may be attributed to seasonal demand of majority of cop production inputs and their uneven distribution. Lack of proper guidance from agricultural department was the second major problem of farmers growing major field crops.

The problem regarding lack of cooperative marketing societies was ranked third by the farmers. Non-availability of regulated market in the vicinity was ranked fourth. Regulated markets ensure fair price to the farmers without any charges. Problem of dominance of traders in market faced by the farmers was ranked fifth. Even after buying the produce, dominant traders delay in making payment or overcharging to the farmers. The problem regarding lack of transportation means ranked sixth by the farmers.

Due to this the farmers sold their produce in local market or mandies at lower price. Short supply of both skilled and unskilled labour was ranked as seventh. It may be attributed to seasonal nature of crop production, heavy demand of labour by the farmers at the peak season. Lack of government assistance in marketing system was ranked as eighth by the farmers. Problem of scarcity of packing materials was ranked ninth. 
Farmers also complained of lack of road facilities as the next major problem in the study area. This facilitates in reducing inputs transaction costs for the farmers. Similar results were reported by Shashikant et al., (2013), Amutha (2011) and Dhaka and Dhaka (2016).

\section{Financial constraints}

It is evident from the table- 10 that the lack of cash for down payment was one of the major problems. This could be attributed to poor financial condition of the farmers. Lack of institutional credit and banking services was the second major problem faced by the farmers. The problem regarding nonavailability of credit for inputs was ranked third. Lack of flexible repayment plans was the next major problem of farmers. High cost of improved implements ranked of number fifth. Problems regarding restrictive or tedious procedure ranked sixth major problem by the farmers. It may be attributed to cumbersome process of getting loans from financial institutions for crop production. Problem of high interest rate faced by the farmers was the next major problem. Similar results were reported by Thanh and Singh (2006).

\section{Other constraints}

The overall scenario of other constraints faced by the cultivators of major field crops revealed that low and imbalanced rate of fertilizer consumption was one of the major problem faced by the farmers of growing major field crops (table- 12).

The farmers reported that there existed a wide gap between credit required and credit supplied which was attributed to the scale fixed by the banks. Problems regarding nonadoption of proper cropping pattern ranked second by the farmers. This was because of uneven and variable climatic conditions in the study area. Low level of education was ranked as third. The problem of migration from agriculture sector was ranked fourth by the farmers. This was attributed to prevailing poor conditions and search for better jobs in another sector for higher wages. The similar results were observed by Thanh and Singh (2006) and Amutha (2011).

Table.1 Percentage positions and their corresponding Garrett's Table values of production constraints

\begin{tabular}{|c|c|c|c|c|}
\hline \multirow{2}{*}{$\begin{array}{c}\text { Rank } \\
1\end{array}$} & \multirow{2}{*}{$\begin{array}{l}\text { Factors } \\
\text { Timely non-availability of inputs like } \\
\text { HYV seeds, chemical fertilizers, plant } \\
\text { protection chemicals etc. at village level }\end{array}$} & \multicolumn{2}{|c|}{ Percentage Position } & \multirow{2}{*}{$\begin{array}{c}\text { Garrett Table } \\
\text { Value } \\
80\end{array}$} \\
\hline & & $100(1-0.5) / 8$ & 6.25 & \\
\hline 2 & Lack of prompt services & $100(2-0.5) / 8$ & 18.75 & 69 \\
\hline 3 & $\begin{array}{l}\text { High costs of improved production } \\
\text { inputs }\end{array}$ & $100(3-0.5) / 8$ & 31.25 & 60 \\
\hline 4 & $\begin{array}{l}\text { Insufficient funds to buy improved } \\
\text { production inputs }\end{array}$ & $100(4-0.5) / 8$ & 43.75 & 53 \\
\hline 5 & $\begin{array}{l}\text { Poor quality seed and plant protection } \\
\text { chemicals }\end{array}$ & $100(5-0.5) / 8$ & 56.25 & 47 \\
\hline 6 & Poor quality lands & $100(6-0.5) / 8$ & 68.75 & 40 \\
\hline 7 & Lack of technical guidance in time & $100(7-0.5) / 8$ & 81.25 & 33 \\
\hline 8 & Poor marketing facility for the produce & $100(8-0.5) / 8$ & 93.75 & 20 \\
\hline
\end{tabular}


Table. 2 Garrett's ranking of production constraints associated with the farmers produces of major field crops in Rajasthan

\begin{tabular}{|c|c|c|c|c|c|}
\hline $\begin{array}{l}\text { S. } \\
\text { No. }\end{array}$ & Factor & $\begin{array}{l}\text { Total No. of } \\
\text { Respondents }\end{array}$ & $\begin{array}{l}\text { Total Scores } \\
\text { in Rajasthan }\end{array}$ & $\begin{array}{l}\text { Total Mean } \\
\text { Score in } \\
\text { Rajasthan }\end{array}$ & $\begin{array}{c}\text { Rank in } \\
\text { Rajasthan }\end{array}$ \\
\hline 1 & $\begin{array}{l}\text { Timely non-availability of inputs } \\
\text { like HYV seeds, chemical } \\
\text { fertilizers, plant protection } \\
\text { chemicals etc. at village level }\end{array}$ & 290 & 17778 & 61.30 & 1 \\
\hline 2 & Lack of prompt services & 290 & 16953 & 58.46 & 4 \\
\hline 3 & $\begin{array}{l}\text { High costs of improved production } \\
\text { inputs }\end{array}$ & 290 & 16411 & 56.59 & 6 \\
\hline 4 & $\begin{array}{l}\text { Insufficient funds to buy improved } \\
\text { production inputs }\end{array}$ & 290 & 16657 & 57.44 & 5 \\
\hline 5 & $\begin{array}{l}\text { Poor quality seed and plant } \\
\text { protection chemicals }\end{array}$ & 290 & 16277 & 56.13 & 7 \\
\hline 6 & Poor quality lands & 290 & 16105 & 55.53 & 8 \\
\hline 7 & Lack of technical guidance in time & 290 & 17086 & 58.92 & 3 \\
\hline 8 & $\begin{array}{l}\text { Poor marketing facility for the } \\
\text { produce }\end{array}$ & 290 & 17353 & 59.84 & 2 \\
\hline
\end{tabular}

Table.3 Percentage positions and their corresponding Garrett's table values of economic constraints

\begin{tabular}{|c|c|c|c|c|}
\hline Rank & Factors & \multicolumn{2}{|c|}{ Percentage Position } & Garrett Table \\
\hline 1 & $\begin{array}{l}\text { Non-availability of loans from banks or } \\
\text { government agencies }\end{array}$ & $100(1-0.5) / 7$ & 7.14 & 78 \\
\hline 2 & High cost of irrigation water & $100(2-0.5) / 7$ & 21.43 & 66 \\
\hline 3 & High cost of fencing boundary wall & $100(3-0.5) / 7$ & 35.71 & 57 \\
\hline 4 & High cost of improved variety seeds & $100(4-0.5) / 7$ & 50.00 & 50 \\
\hline 5 & High cost of fertilizer & $100(5-0.5) / 7$ & 64.29 & 43 \\
\hline 6 & Low and fluctuating prices & $100(6-0.5) / 7$ & 78.57 & 34 \\
\hline 7 & Shortage of human labour & $100(7-0.5) / 7$ & 92.86 & 21 \\
\hline
\end{tabular}

Table.4 Garrett's ranking of economic constraints associated with the producer farmers of the major field crops in Rajasthan

\begin{tabular}{|c|l|c|c|c|c|}
\hline $\begin{array}{c}\text { S. } \\
\text { No. }\end{array}$ & \multicolumn{1}{|c|}{ Factor } & $\begin{array}{c}\text { Total No. of } \\
\text { Respondents }\end{array}$ & $\begin{array}{c}\text { Total Scores in } \\
\text { Rajasthan }\end{array}$ & $\begin{array}{c}\text { Total Mean } \\
\text { Score in } \\
\text { Rajasthan }\end{array}$ & $\begin{array}{c}\text { Rank in } \\
\text { Rajasthan }\end{array}$ \\
\hline 1 & $\begin{array}{l}\text { Non-availability of loans from } \\
\text { banks or government agencies }\end{array}$ & 290 & 17689 & 61.00 & 3 \\
\hline 2 & High cost of irrigation water & 290 & 16961 & 58.49 & 6 \\
\hline 3 & $\begin{array}{l}\text { High cost of fencing boundary } \\
\text { wall }\end{array}$ & 290 & 18097 & 62.40 & 2 \\
\hline 4 & $\begin{array}{l}\text { High cost of improved variety } \\
\text { seeds }\end{array}$ & 290 & 18474 & 63.70 & 1 \\
\hline 5 & High cost of fertilizer & 290 & 17244 & 59.46 & 5 \\
\hline 6 & Low and fluctuating prices & 290 & 17352 & 59.83 & 4 \\
\hline 7 & Shortage of human labour & 290 & 16748 & 57.75 & 7 \\
\hline
\end{tabular}


Table.5 Percentage positions and their corresponding Garrett's table values of technical constraints

\begin{tabular}{|c|c|c|c|c|}
\hline Rank & Factors & \multicolumn{2}{|c|}{ Percentage Position } & Garrett Table \\
\hline 1 & $\begin{array}{l}\text { Lack of technical knowledge about } \\
\text { crop cultivation }\end{array}$ & $100(1-0.5) / 9$ & 5.56 & 81 \\
\hline 2 & Lack of irrigation facilities & $100(2-0.5) / 9$ & 16.67 & 70 \\
\hline 3 & $\begin{array}{l}\text { No protection of crops from adverse } \\
\text { weather conditions }\end{array}$ & $100(3-0.5) / 9$ & 27.78 & 62 \\
\hline 4 & $\begin{array}{l}\text { No lack of knowledge of name and } \\
\text { doses of manures, fertilizers and } \\
\text { chemicals }\end{array}$ & $100(4-0.5) / 9$ & 38.89 & 56. \\
\hline 5 & Lack of soil testing facilities & $100(5-0.5) / 9$ & 50.00 & 50 \\
\hline 6 & Incidence of diseases & $100(6-0.5) / 9$ & 61.11 & 44 \\
\hline 7 & Poor crop germination & $100(7-0.5) / 9$ & 72.22 & 38 \\
\hline 8 & $\begin{array}{l}\text { Limited use of short duration HYV } \\
\text { seed }\end{array}$ & $100(8-0.5) / 9$ & 83.33 & 31 \\
\hline 9 & $\begin{array}{l}\text { No directions and encouragement from } \\
\text { government for crop cultivation }\end{array}$ & $100(9-0.5) / 9$ & 94.44 & 19 \\
\hline
\end{tabular}

Table.6 Garrett's ranking of technical constraints associated with the producer farmers the major field crops in Rajasthan

\begin{tabular}{|c|c|c|c|c|c|}
\hline $\begin{array}{l}\text { S. } \\
\text { No. }\end{array}$ & Factor & $\begin{array}{l}\text { Total No. of } \\
\text { Respondents }\end{array}$ & $\begin{array}{l}\text { Total Scores } \\
\text { in Rajasthan }\end{array}$ & $\begin{array}{l}\text { Total Mean } \\
\text { Score in } \\
\text { Rajasthan }\end{array}$ & $\begin{array}{c}\text { Rank in } \\
\text { Rajasthan }\end{array}$ \\
\hline $\mathbf{1}$ & $\begin{array}{l}\text { Lack of technical knowledge } \\
\text { about crop cultivation }\end{array}$ & 290 & 17682 & 60.97 & 3 \\
\hline 2 & Lack of irrigation facilities & 290 & 18219 & 62.82 & 1 \\
\hline 3 & $\begin{array}{l}\text { No protection of crops from } \\
\text { adverse weather conditions }\end{array}$ & 290 & 17927 & 61.82 & 2 \\
\hline 4 & $\begin{array}{l}\text { No lack of knowledge of } \\
\text { name and doses of manures, } \\
\text { fertilizers and chemicals }\end{array}$ & 290 & 17476 & 60.26 & 4 \\
\hline 5 & Lack of soil testing facilities & 290 & 16614 & 57.29 & 8 \\
\hline 6 & Incidence of diseases & 290 & 17059 & 58.82 & 6 \\
\hline 7 & Poor crop germination & 290 & 16892 & 58.25 & 7 \\
\hline 8 & $\begin{array}{l}\text { Limited use of short duration } \\
\text { HYV seed }\end{array}$ & 290 & 17213 & 59.36 & 5 \\
\hline 9 & $\begin{array}{l}\text { No directions and } \\
\text { encouragement from } \\
\text { government for crop } \\
\text { cultivation }\end{array}$ & 290 & 16375 & 56.47 & 9 \\
\hline
\end{tabular}


Table.7 Percentage positions and their corresponding Garrett's table values of Infrastructural constraints

\begin{tabular}{|c|l|c|c|c|}
\hline Rank & \multicolumn{1}{|c|}{ Factors } & \multicolumn{1}{|c|}{ Percentage Position } & $\begin{array}{c}\text { Garrett } \\
\text { Table Value }\end{array}$ \\
\hline $\mathbf{1}$ & $\begin{array}{l}\text { Lack of proper guidance by Agricultural } \\
\text { department }\end{array}$ & $100(1-0.5) / 10$ & 5.00 & 82 \\
\hline $\mathbf{2}$ & Lack of cooperative marketing societies & $100(2-0.5) / 10$ & 15.00 & 70 \\
\hline $\mathbf{3}$ & $\begin{array}{l}\text { The inputs needed for production of crops } \\
\text { are not timely available in the market }\end{array}$ & $100(3-0.5) / 10$ & 25.00 & 63 \\
\hline $\mathbf{4}$ & $\begin{array}{l}\text { Short supply of both skilled and unskilled } \\
\text { labourers }\end{array}$ & $100(4-0.5) / 10$ & 35.00 & 58 \\
\hline $\mathbf{5}$ & Scarcity of packing materials & $100(5-0.5) / 10$ & 45.00 & 52 \\
\hline $\mathbf{6}$ & Dominance of traders in market & $100(6-0.5) / 10$ & 55.00 & 48 \\
\hline $\mathbf{7}$ & Non availability of regulated markets & $100(7-0.5) / 10$ & 65.00 & 42 \\
\hline $\mathbf{8}$ & Lack of transport means & $100(8-0.5) / 10$ & 75.00 & 37 \\
\hline $\mathbf{9}$ & Lack of road facilities & $100(9-0.5) / 10$ & 85.00 & 30 \\
\hline $\mathbf{1 0}$ & Lack of Government assistance in & $100(10-0.5) / 10$ & 95.00 & 18 \\
\hline
\end{tabular}

Table.8 Garrett's ranking of Infrastructural constraints associated with the producer farmers of the major field crops in Rajasthan

\begin{tabular}{|c|l|c|c|c|c|}
\hline $\begin{array}{c}\text { S. } \\
\text { No. }\end{array}$ & \multicolumn{1}{|c|}{ Factor } & $\begin{array}{c}\text { Total No. of } \\
\text { Respondents }\end{array}$ & $\begin{array}{c}\text { Total Scores } \\
\text { in Rajasthan }\end{array}$ & $\begin{array}{c}\text { Total Mean } \\
\text { Score in } \\
\text { Rajasthan }\end{array}$ & $\begin{array}{c}\text { Rank in } \\
\text { Rajasthan }\end{array}$ \\
\hline $\mathbf{1}$ & $\begin{array}{l}\text { Lack of proper guidance by } \\
\text { Agricultural department }\end{array}$ & 290 & 18990 & 65.48 & 2 \\
\hline $\mathbf{2}$ & $\begin{array}{l}\text { Lack of cooperative } \\
\text { marketing societies }\end{array}$ & 290 & 18729 & 64.58 & 3 \\
\hline $\mathbf{3}$ & $\begin{array}{l}\text { The inputs needed for } \\
\text { production of crops are not } \\
\text { timely available in the } \\
\text { market }\end{array}$ & 290 & 19438 & 67.03 & 1 \\
\hline $\mathbf{4}$ & $\begin{array}{l}\text { Short supply of both skilled } \\
\text { and unskilled labourers }\end{array}$ & 290 & 17739 & 61.17 & 7 \\
\hline $\mathbf{5}$ & $\begin{array}{l}\text { Scarcity of packing } \\
\text { materials }\end{array}$ & 290 & 17316 & 59.71 & 9 \\
\hline $\mathbf{6}$ & $\begin{array}{l}\text { Dominance of traders in } \\
\text { market }\end{array}$ & 290 & 18477 & 63.71 & 5 \\
\hline $\mathbf{7}$ & $\begin{array}{l}\text { Non availability of } \\
\text { regulated markets }\end{array}$ & 290 & 18584 & 64.08 & 4 \\
\hline $\mathbf{8}$ & Lack of transport means & 290 & 18090 & 62.38 & 6 \\
\hline $\mathbf{9}$ & Lack of road facilities & 290 & 16750 & 57.76 & 10 \\
\hline $\mathbf{1 0}$ & $\begin{array}{l}\text { Lack of Government } \\
\text { assistance in marketing } \\
\text { system }\end{array}$ & 290 & 17529 & 60.44 & 8 \\
\hline & & & & & 5 \\
\hline
\end{tabular}


Table.9 Percentage positions and their corresponding Garrett's Table values of financial constraints

\begin{tabular}{|l|l|c|c|c|}
\hline Rank & \multicolumn{1}{|c|}{ Rank } & \multicolumn{1}{|c|}{ Percentage Position } & $\begin{array}{c}\text { Garrett } \\
\text { Table Value }\end{array}$ \\
\hline $\mathbf{1}$ & Lack of cash for down payment & $100(1-0.5) / 7$ & 7.14 & 78 \\
\hline $\mathbf{2}$ & High interest rate & $100(2-0.5) / 7$ & 21.43 & 66 \\
\hline $\mathbf{3}$ & Lack of flexible repayment plans & $100(3-0.5) / 7$ & 35.71 & 57 \\
\hline $\mathbf{4}$ & Restrictive or tedious procedure & $100(4-0.5) / 7$ & 50.00 & 50 \\
\hline $\mathbf{5}$ & Lack of institutional credit and banking services & $100(5-0.5) / 7$ & 64.29 & 43 \\
\hline $\mathbf{6}$ & High cost of improved implements & $100(6-0.5) / 7$ & 78.57 & 34 \\
\hline $\mathbf{7}$ & Non availability of credit for inputs & $100(7-0.5) / 7$ & 92.86 & 21 \\
\hline
\end{tabular}

Table.10 Garrett's ranking of financial constraints associated with the producers farmers of the major field crops in Rajasthan

\begin{tabular}{|c|l|c|c|c|c|}
\hline $\begin{array}{c}\text { S. } \\
\text { No. }\end{array}$ & \multicolumn{1}{|c|}{ Factor } & $\begin{array}{c}\text { Total No. of } \\
\text { Respondents }\end{array}$ & $\begin{array}{c}\text { Total Scores } \\
\text { in Rajasthan }\end{array}$ & $\begin{array}{c}\text { Total Mean } \\
\text { Score in } \\
\text { Rajasthan }\end{array}$ & $\begin{array}{c}\text { Rank in } \\
\text { Rajasthan }\end{array}$ \\
\hline $\mathbf{1}$ & $\begin{array}{l}\text { Lack of cash for down } \\
\text { payment }\end{array}$ & 290 & 18351 & 63.28 & 1 \\
\hline $\mathbf{2}$ & High interest rate & 290 & 16632 & 57.35 & 7 \\
\hline $\mathbf{3}$ & $\begin{array}{l}\text { Lack of flexible repayment } \\
\text { plans }\end{array}$ & 290 & 17443 & 60.15 & 4 \\
\hline $\mathbf{4}$ & $\begin{array}{l}\text { Restrictive or tedious } \\
\text { procedure }\end{array}$ & 290 & 16963 & 58.49 & 6 \\
\hline $\mathbf{5}$ & $\begin{array}{l}\text { Lack of institutional credit } \\
\text { and banking services }\end{array}$ & 290 & 18123 & 62.49 & 2 \\
\hline $\mathbf{6}$ & $\begin{array}{l}\text { High cost of improved } \\
\text { implements }\end{array}$ & 290 & 17284 & 59.60 & 5 \\
\hline $\mathbf{7}$ & $\begin{array}{l}\text { Non availability of credit } \\
\text { for inputs }\end{array}$ & 290 & 17743 & 61.18 & 3 \\
\hline
\end{tabular}

Table.11 Percentage Positions and their corresponding Garrett's Table values of other constraints

\begin{tabular}{|c|l|c|c|c|}
\hline Rank & \multicolumn{1}{|c|}{ Rank } & \multicolumn{2}{|c|}{ Percentage Position } & $\begin{array}{c}\text { Garrett Table } \\
\text { Value }\end{array}$ \\
\hline $\mathbf{1}$ & $\begin{array}{l}\text { Low and imbalanced rate of } \\
\text { fertilizer consumption }\end{array}$ & $100(1-0.5) / 4$ & 12.50 & 73 \\
\hline $\mathbf{2}$ & $\begin{array}{l}\text { Non-adoption of proper cropping } \\
\text { pattern }\end{array}$ & $100(2-0.5) / 4$ & 37.50 & 56 \\
\hline $\mathbf{3}$ & Migration from agriculture sector & $100(3-0.5) / 4$ & 62.50 & 44 \\
\hline $\mathbf{4}$ & Low level of education & $100(4-0.5) / 4$ & 87.50 & 27 \\
\hline
\end{tabular}


Table.12 Garrett's ranking of other constraints associated with the producer farmers of the major field crops in Rajasthan

\begin{tabular}{|c|l|c|c|c|c|}
\hline $\begin{array}{c}\text { S. } \\
\text { No. }\end{array}$ & \multicolumn{1}{|c|}{ Factor } & $\begin{array}{c}\text { Total No. of } \\
\text { Respondents }\end{array}$ & $\begin{array}{c}\text { Total Scores in } \\
\text { Rajasthan }\end{array}$ & $\begin{array}{c}\text { Total Mean } \\
\text { Score in } \\
\text { Rajasthan }\end{array}$ & $\begin{array}{c}\text { Rank in } \\
\text { Rajasthan }\end{array}$ \\
\hline $\mathbf{1}$ & $\begin{array}{l}\text { Low and imbalanced } \\
\text { rate of fertilizer } \\
\text { consumption }\end{array}$ & 290 & 17602 & 60.70 & 1 \\
\hline $\mathbf{2}$ & $\begin{array}{l}\text { Non-adoption of } \\
\text { proper cropping } \\
\text { pattern }\end{array}$ & 290 & 16978 & 58.54 & 2 \\
\hline $\mathbf{3}$ & $\begin{array}{l}\text { Migration from } \\
\text { agriculture sector }\end{array}$ & 290 & 16166 & 55.74 & 4 \\
\hline $\mathbf{4}$ & $\begin{array}{l}\text { Low level of } \\
\text { education }\end{array}$ & 290 & 16614 & 57.29 & 3 \\
\hline
\end{tabular}

The timely non-availability of inputs at village level like HYV seeds, chemical fertilizers, plant protection chemicals etc was the major production constraints faced by the cultivators of major field crops. High cost of improved variety seeds was the major economic problem reported by the farmers. The lack of irrigation facilities was one of the major technical problems in the study area. Timely non availability of inputs needed for production of crops in the market constituted the major infrastructural problem. Lack of cash for down payment was one of the major financial problems and low and imbalanced rate of fertilizer consumption was one of the other major problems faced by the farmers growing major field crops.

\section{References}

Amutha, D. (2011). "Constraints and techniques for improving pulses production in Tamil Nadu, India". International Journal of Bio-resource and Stress Management, 2(2): 159-162.

Dhaka, S.R. and Dhaka, B.L. (2016). "Analysis of productivity constraints faced by farmers in Tonk District of Rajasthan". International Journal of Science, Environment and Technology,
5(2): $799-805$.

Garrett, H.E. and Woodworth, R.S. (1969). "Statistics in Psychology and Education". Vakils, Feffer and Simons Pvt. Ltd. Bombay. 329.

Gupta, S.K. (2001). "Economics of pulses production and identification of constraints in raising their production (a consolidated report of AERC studies)". Ad-hoc Study-Agro-Economic Research Centre for Madhya Pradesh, Jawaharlal Nehru Krishi Vishwa Vidyalay, 79 (177).

Prakash, A., Singh, H.N., Shekhawat, R.S. and Sandu, S. (2017). "Constraints faced by farmers in production of inbred and hybrid rice in Udham Singh Nagar district of Uttarakhand, India". International Journal of Current Microbiology and Applied Sciences, 6(12) : 2243-2247.

Shashikant, V. G., Dubey, L. R. and Arpita Kotnala (2013). "Constraints faced by red gram growers in Gulbarga district of Karnataka". Environment and Ecology; vol.- 31(2): 440-443.

Shrey, R., Bante, R., Pallewar, S., Acharya, G. K. and Dhurwey, C. (2015). "Constraints perceived by farmers in crop-dairy mixed farming system on 
small farms in parbhani district of Marathwada Region (Maharashtra), India." Plant Archives, 15(1): 41-46.

Thanh, N. C. and Singh, Baldeo (2006). "Constraints faced by the farmers in rice production and export". Cuu Long Delta Rice Research Institute, Head of the Division of Agricultural Extension, IARI, New Delhi, India, Omonrice -14 $: 1-14$.

\section{How to cite this article:}

Verma. B. L. and Kumawat. R. C. 2020. Constraints being Faced by the Farmers in the Production of Major Field Crops in the State of Rajasthan, India. Int.J.Curr.Microbiol.App.Sci. 9(06): 1763-1773. doi: https://doi.org/10.20546/ijcmas.2020.906.220 